\title{
HUBUNGAN PENGETAHUAN PERAWAT DENGAN KEPATUHAN PERAWAT MENGISI IDENTITAS PASIEN
}

\section{CORRELATION OF NURSING KNOWLEDGE WITH NURSING COMPLIANCE FILLING PATIENT IDENTITY}

\author{
Fitra Pringgayuda ${ }^{1}$, Nur hasanah ${ }^{1}$, Daniah $^{2}$ \\ ${ }^{1}$ Fakultas Kesehatan, Universitas Muhammadiyah Pringsewu \\ ${ }^{2}$ RS Mitra Husada \\ e-mail: fpringgayuda@yahoo.com
}

\begin{abstract}
ABSTRAK
Kepatuhan perawat mengisi identitas pasien merupakan kegiatan sesuai Standar Operasional Prosedur atau aturan dalam mengisi identitas pasien meliputi nama, nomor rekam medis, dan tanggal lahir. Tujuan penelitian ini diketahuinya hubungan pengetahuan perawat dengan kepatuhan perawat mengisi identitas pasien di ruang rawat inap rumah sakit mitra husada pringsewu lampung tahun 2020. Penelitian ini menggunakan survey analitik dengan pendekatan cross sectional. Sampel dalam penelitian ini adalah perawat ruang rawat inap di rumah sakit Mitra Husada Pringsewu yaitu sebanyak 108 orang dengan tehnik purposive sampling. Hasil uji statistik chi square didapat nilai $p$-value $<0,001$ hal ini menyatakan bahwa ada hubungan yang signifikan antara pengetahuan perawat dengan kepatuhan perawat mengisi identitas pasien di ruang rawat inap rumah sakit Mitra Husada Pringsewu Lampung Tahun 2020.
\end{abstract}

Kata kunci : identitas pasien, kepatuhan, pengetahuan

\begin{abstract}
Nurse compliance to fill patient identity is to obey orders, obey orders or rules and be disciplined in filling patient identity (name, medical record number, and date of birth) carried out by nurses in which compliance is closely related to nurses' knowledge. The aim of this study was to determine the relationship of nurses 'knowledge with nurses' compliance filling patient identity in inpatients at Mitra Husada Pringsewu Lampung Hospital in 2020. This study used analytic surveys with cross sectional approach. The sample in this study was inpatient nurses in Mitra Husada Pringsewu Hospital, as many as 108 people with purposive sampling techniques. Chi square statistical test results obtained p-value $<0,001$, this states that there is a significant relationship between knowledge of nurses and nurses' compliance with filling patient identity in inpatients at Mitra Husada Pringsewu Hospital Lampung in 2020.
\end{abstract}

Keywords : compliance, knowledge, patient identity 


\section{PENDAHULUAN}

Institusi Pelayanan Kesehatan yang melayani masyarakat dengan sistem yang komplek dan memerlukan system informasi dalam menjalankan kegiatannya adalah Rumah Sakit. Sistem informasi didalam Rumah sakit dalam pelayanan pasien salah satunya adalah Rekam medis. Rekam medis merupakan sumber data utama yang berisi catatan perawatan, diagnosis medis, pengobatan, dan proses perkembangan pasien. Sebagai sumber data utama, rekam medis dapat digunakan untuk kepentingan pembelajaran dan research serta aspek legal formal dan legal etik ${ }^{1}$.

Dokumen rekam medis/catatan pengobatan dan perawatan pasien dapat menggambarkan kualitas pelayanan sebuah institusi kesehatan, diantaranya yang paling penting adalah akurasi dan kesesuaian identitas pasien di dalam dokumen rekam medis ${ }^{2}$.

Identitas pasien pada dokumen rekam medik yang tidak sesuai masih tinggi di tahun 2018. Pengisian dokumen rekam medik khususnya identitas pasien, di Vietnam 47\%, Kamboja 45\%, Kanada $31 \%$, dan Amerika 20\%3. Data rekam medis yang tidak lengkap di Indonesia menunjukkan $37 \%$. Hal tersebut kemungkinan disebabkan oleh sistem informasi yang kurang baik, dan pengetahuan petugas tentang pentingnya pengisian dan kelengkapan dokumen rekam medik ${ }^{4}$. PMKP di RS Mitra Husada Pringsewu 2019, insiden tertukarnya pasien, nyaris salah pemberian obat, disebabkan oleh kelengkapan pengisian identitas pasien di ruang rawat inap Rumah Sakit Mitra Husada Pringsewu.
Hasil studi pendahuluan 2 Desember 2019 melalui observasi, kelengkapan pengisian identitas pasien, 12 perawat mengisi tidak lengkap, 8 perawat mengisi lengkap. Wawancara tentang pentingnya mengisi identitas pasien secara lengkap, 11 perawat tidak mengetahui tentang pentingnya melengkapi identitas pasien, 9 perawat mengatakan mengetahui pentingnya melengkapi identitas pasien. Data tersebut menunjukkan pengetahuan perawat belum semua mengetahui pentingya menulis secara lengkap identitas pasien.

\section{METODE}

Desain penelitian ini survei analitik dengan cross sectional ${ }^{5}$. Variabel dependen dan variabel independen diobservasi hanya sekali. Populasi pada penelitian ini adalah perawat ruang rawat inap di Rumah Sakit Mitra Husada Pringsewu. Sampel 108 perawat dengan teknik purposive sampling ${ }^{6}$.

Pengumpulan data tentang pengetahuan perawat menggunakan instrument kuesioner. Lembar Observasi untuk mengetahui pengisian rekam medik (nama, nomor rekam medis, dan tanggal lahir) dalam satu shift. 
HASIL

\section{Tabel .1}

Karakteristik responden berdasarkan pengetahuan di ruang rawat inap RS Mitra Husada Pringsewu Lampung

Tahun 2020.

Pengetahuan Frekuensi Presentase perawat

$\%$

\begin{tabular}{lcc}
\hline Baik & 44 & 40,7 \\
Cukup & 57 & 52,8 \\
Kurang & 7 & 6,5 \\
\hline Jumlah & 108 & 100.0
\end{tabular}

Berdasarkan tabel diatas diketahui bahwa sebagian besar responden memiliki pengetahuan yang cukup yaitu sebanyak 57 responden $(52,8 \%)$.

Tabel. 2

Distribusi frekuensi berdasarkan Pendidikan dan masa kerja perawat di ruang rawat inap RS Mitra Husada Pringsewu Lampung

Tahun 2020.

\begin{tabular}{lcc}
\hline Karakteristik & Frekuensi & $\begin{array}{c}\text { Presentase } \\
\mathbf{\%}\end{array}$ \\
\hline Pendidikan & & \\
DIII & 23 & 21,3 \\
Keperawatan & 85 & 78,7 \\
$\quad$ Ners & 108 & 100.0 \\
\hline Jumlah & & \\
Masa Kerja & 30 & 27,8 \\
$\leq 3$ tahun & 78 & 72,2 \\
\hline 3 tahun & 108 & 100 \\
\hline Jumlah & & \\
\hline
\end{tabular}

Berdasarkan tabel diatas, diketahui bahwa sebagian besar responden berpendidikan Ners yaitu sebanyak 85 responden $(78,7 \%)$ dan responden sebagian besar memiliki masa kerja $>3$ tahun yaitu sebanyak $78 \quad(72,2 \%)$ responden.
Tabel .3

Distribusi frekuensi berdasarkan kepatuhan perawat mengisi identitas pasien di ruang rawat inap RS Mitra Husada Pringsewu Lampung Tahun 2020

\begin{tabular}{lcc}
\hline $\begin{array}{l}\text { Kepatuhan } \\
\text { perawat }\end{array}$ & Frekuensi & $\begin{array}{c}\text { Presentase } \\
\%\end{array}$ \\
\hline Patuh & 74 & 68,5 \\
Tidak patuh & 34 & 31,5 \\
\hline Jumlah & 108 & 100.0 \\
\hline
\end{tabular}

Berdasarkan tabel diatas diketahui bahwa sebagian besar responden patuh dalam mengisi identitas pasien yaitu sebanyak 74 responden $(68,5 \%)$.

\section{Tabel 4}

Hubungan pengetahuan perawat dengan kepatuhan perawat mengisi identitas pasien di ruang rawat inap

RS Mitra Husada Pringsewu Lampung tahun 2020.

\begin{tabular}{|c|c|c|c|c|}
\hline \multirow{2}{*}{$\begin{array}{l}\text { Pengetahuan } \\
\text { perawat }\end{array}$} & \multicolumn{4}{|c|}{$\begin{array}{l}\text { Kepatuhan perawat mengisi } \\
\text { identitas pasien }\end{array}$} \\
\hline & \multicolumn{2}{|c|}{ Patuh } & \multicolumn{2}{|c|}{$\begin{array}{l}\text { Tidak } \\
\text { patuh }\end{array}$} \\
\hline & $\mathrm{N}$ & $\%$ & $\mathrm{~N}$ & $\%$ \\
\hline Baik & 43 & 39,8 & 1 & 0,9 \\
\hline Cukup & 29 & 26,8 & 28 & 25,9 \\
\hline Kurang baik & 2 & 1,8 & 5 & 4,6 \\
\hline Jumlah & 74 & 68,5 & 34 & 31,5 \\
\hline Total & $\mathrm{N}$ & $\%$ & $\begin{array}{c}\mathrm{p}- \\
\text { value }\end{array}$ & \\
\hline Baik & 44 & 40,7 & \multirow{4}{*}{0,000} & \\
\hline Cukup & 57 & 52,8 & & \\
\hline Kurang Baik & 7 & 6,5 & & \\
\hline Jumlah & 108 & 100 & & \\
\hline \multicolumn{5}{|c|}{$\begin{array}{l}\text { Berdasarkan tabel diatas diketahui } \\
\text { responden memiliki pengetahuan baik } \\
\text { dan patuh dalam mengisi identitas } \\
\text { pasien yaitu sebanyak } 43 \text { resonden }\end{array}$} \\
\hline
\end{tabular}


$(39,8 \%)$ dan berdasarkan hasil uji statistic chi-square diketahui bahwa $p$ value $<0,001$. Hal ini menunjukan ada hubungan Antara pengetahuan perawat dengan kepatuhan perawat mengisi identitas pasien di ruang rawat inap Rumah Sakit Mitra Husada Pringsewu Lampung Tahun 2020.

\section{PEMBAHASAN}

\section{Frekuensi pengetahuan perawat}

Hasil penelitian menunjukkan bahwa sebagian besar responden memiliki pengetahuan yang cukup yaitu sebanyak 57 responden $(52,8 \%)$ hal ini dapat dilihat tingkat Pendidikan perawat berbanding lurus dengan lama masa kerja. Sejalan dengan hasil penelitian terdahulu bahwa responden yang memiliki Pendidikan ners sejumlah 85 $(78,7 \%)$ dan responden dengan masa lebih dari 3 tahun sejumlah 78 $(72,2 \%)^{7}$.

Pendidikan dan masa kerja seseorang / individu sangat mempengaruhi pekerjaan yang dilakukan. Dengan semakin tingginya Pendidikan akan berbanding lurus dengan pengetahuannya, dan semakin lama masa kerjanya berkaitan dengan pengalaman kerja dan semakin menyadarkan akan pentingnya bekerja dengan baik, sesuai dengan pengalamannya. Seorang Perawat berpendidikan tinggi dan memiliki masa kerja yang cukup cendrung memiliki pengetahuan yang baik. Pengalaman, akan membuka wawasan dalam bertindak dan cenderung akan lebih berhati-hati dalam melakukan sebuah Tindakan sampai dengan mendokumentasikan identitas pasien secara lengkap pada dokumen rekam medik. Dengan Pendidikan dan masa kerja yang cukup juga akan menyadarkan akan pentingnya pendokumentasian dalam rekam medik yang pasti akan memiliki dampak hukum jika terjadi kekeliruan dalam pengisian dokumen rekam medik.

Sejalan dengan penelitian terdahulu yang menyatakan bahwa responden berpendidikan ners berbanding lurus dengan tingginya pengetahuan perawat tentang pengisian dokumen rekam medik, dengan perbandingan pendidikan ners $52,4 \%$ sedangkan pengetahuan perawat sebesar $58,85 \%{ }^{8}$.

Menurut pendapat peneliti jumlah perawat dengan pengetahuan yang cukup, dapat dipengaruhi oleh tingkat pendidikan dan pengalaman kerja / masa $\mathrm{kerja}^{7}$. Semakin lama masa kerja seorang perawat, akan memiliki pengalaman dan meluaskan wawasan dan kinerjanya semakin baik ${ }^{5}$.Masa kerja yang lama, akan mengasah kemampuan,mengembangkan pengetahuan sehingga perbaikan dalam bekerja terjadi.

\section{Frekuensi kepatuhan perawat mengisi identitas pasien}

Hasil penelitian ini responden yang patuh dalam mengisi identitas pasien yaitu sejumlah 74 responden $(68,5 \%)$ ini dipengaruhi tingkat pengetahuan perawat tentang bagaimana mengisi dokumen rekam medik dalam hal ini identitas pasien. Sejalan dengan penelitian terdahulu yang menyatakan bahwa pengetahuan yang cukup baik $(52,8 \%)$, akan mempengaruhi seseorang perawat dalam mengisi dokumen rekam medis khususnya identitas pasien'. 
Pengetahuan yang baik dari seorang perawat maka akan semakin menyadarkan pentingnya mengikuti peraturan yang ada.

Hasil penelitian ini juga sejalan dengan penelitian terdahulu, yang menganalisis faktor pengetahuan, motivasi, dan persepsi perawat tentang supervisi kepala ruang terhadap proses penatalaksanaan dokumentasi asuhan keperawatan di ruang rawat inap. Hasil penelitian tersebut menyampaikan bahwa $51,6 \%$ perawat berpengetahuan yang baik berbanding lurus dengan pengisian dan kelengkapan dokumentasi asuhan keperawatan yang dilakukan perawat $58,1 \%{ }^{10}$.

Peneliti berpendapat bahwa masih adanya perawat yang tidak patuh dalam mengisi identitas pasien, ini disebabkan kurangnya pemahaman dan pengetahuan perawat serta kurangnya kesadaran perawat untuk mengisi secara lengkap dokumen rekam medis khususnya identitas pasien. Faktor lain yang mempengaruhi adalah beban kerja perawat yang masih mengerjakan pekerjaan lain, dan perbandingan antara jumlah pasien dan jumlah perawat sehingga dokumentasi didalam rekam medis khususnya identitas pasien kurang lengkap.

\section{Hubungan pengetahuan dengan kepatuhan perawat mengisi identitas pasien di ruang rawat inap rumah sakit Mitra Husada Pringsewu Lampung tahun 2020}

Hasil uji statistik chi-square diketahui bahwa $p$-value $<0,001$ sehingga Ho gagal diterima. Hal ini berarti bahwa terdapat hubungan pengetahuan dengan kepatuhan perawat mengisi identitas pasien di ruang rawat inap rumah sakit Mitra Husada Pringsewu Lampung tahun 2020 .

Hasil penelitian ini sejalan dengan penelitian yang telah dilakukan peneliti lain yang menyatakan bahwa faktor yang mempengaruhi kepatuhan perawat dalam mengisi identitas pasien di dokumen rekam medis salah satunya adalah pengetahuan ${ }^{11}$.

Salah satu yang mempengaruhi perilaku dan aktifitas seseorang adalah pengetahuan. Semakin tingkat pengetahuannya baik, maka seseorang akan semakin berhati-hati dan teliti melakukan pekerjaannya. Pengisian dokumen rekam medik juga akan semakin hati-hati, khususnya pengisian identitas pasien karena menyangkut aspek lagal formal. Pengetahuan merupakan salah satu faktor yang mempengaruhi Tindakan seseorang, aktifitas seseorang yang memiliki pengetahuan akan selalu melalui proses berfikir yang didasarkan atas pengetahuannya. Perawat yang memiliki pengetahuan yang baik akan menunjukkan aktifitasnya tergambar pada perilaku dan kebiasaan yang baik yaitu selalu melengkapi dokumen rekam medik, khususnya identitas pasien seperti nama, tanggal lahir, dan nomor rekam medis. Dengan pengetahuan yang baik akan menumbuhkan kesadaran pentingnya mengisi identitas pasien dengan lengkap. Dan meminimalkan resiko kesalahan pasien dan kesalahan pengobatan, serta dengan dokumentasi yang baik berdampak pada aspek legal formal saat diperlukan. 
Hasil penelitian ini juga sesuai dengan teori pengetahuan perawat yang menyatakan tentang aspek-aspek dokumen rekam medik dapat memengaruhi perawat dalam mengisi kelengkapan identitas pasien $^{12}$.

Seseorang memperoleh pengetahuan dari berbagai hal, diantaranya adalah pendidikan, pelatihan, serta pengalaman di lapangan. Pendidikan, pelatihan, dan pengalaman terbukti akan mempengaruhi perubahan perilaku yang didasari oleh pengetahuannya. Perilaku yang dilandasi dari pengetahuan memiliki efek kepada aktifitas perawat akan lebih berhati-hati di dalam mengisi dokumen rekam medik khususnya mengisi identitas pasien seperti nama, tanggal lahir dan nomor rekam medis.

Penelitian terdahulu yang dilakukan di RSUM Djamil bahwa pengetahuan perawat yang kurang baik tentang rekam medik mempengaruhi pengisian dokumen rekam medik. Hasil penelitian tersebut dilaporkan terdapat hubungan yang signifikan antara pengetahuan dengan kelengkapan pengisian dokumen rekam medis ${ }^{13}$.

Hasil penelitian yang terkait tentang analisis faktor pengetahuan, motivasi, dan persepsi perawat terhadap supervisi kepala ruang dan penatalaksanaan dokumentasi asuhan keperawatan, menyatakan bahwa jika faktor pengetahuan perawat baik, pendokumentasian proses asuhan keperawatan juga baik ${ }^{14}$. Dengan demikian penelitian tersebut menyimpulkan bahwa ada hubungan antara faktor pengetahuan perawat terhadap pelaksanaan dokumentasi asuhan keperawatan.
Peneliti juga berpendapat sama dengan penelitian tersebut. Jika responden memiliki pengetahuan baik maka dalam melaksanakan pekerjaannya sebagai perawat cenderung akan mematuhi aturan khususnya pengisian dokumen rekam medik khususnya identitas pasien. Sebaliknya responden yang memiliki pengetahuan kurang meningkatkan persentasi perawat untuk tidak patuh dalam mengisi identitas pasien. Hal ini sesuai dengan hasil penelitian yang mana terdapat 43 responden yang memiliki pengetahuan baik dan patuh dalam mengisi identitas pasien, sementara dapat 5 responden yang memiliki pengetahuan kurang dan tidak patuh dalam mengisi identitas pasien.

Pengetahuan merupakan salah satu faktor yang dapat mempengaruhi perawat rajin untuk mengisi identitas pasien, namun terdapat responden yang memiliki pengetahuan yang baik namun tidak rajin mengisi identitas pasien yaitu sebanyak 1 responden $(0,92 \%)$, hal tersebut dipengaruhi oleh beberapa faktor lain seperti motivasi, reward, beban kerja, serta status kepegawaian ${ }^{15}$.

Kendala saat pelaksanaan penelitian yang sering ditemukan adalah kurang terstruktur dalam pembagian tugas dan masih belum jelas siapa yang bertanggung jawab mengisi list pasien sehingga peneliti sulit menentukan perawat yang dijadikan responden dalam penelitian ini dan minimnya jumlah perawat tidak sebanding dengan jumlah pasien sehingga perawat seringkali lupa untuk menulis identitas pasien di dalam rekam medis. 


\section{KESIMPULAN}

Ada hubungan yang signifikan antara pengetahuan perawat dengan kepatuhan perawat dalam mengisi dokumen rekam medis dalam hal ini identitas pasien di ruang rawat inap Rumah Sakit Mitra Husada Pringsewu Lampung Tahun 2020 dengan nilai $p$ value $<0,001$.

\section{DAFTAR PUSTAKA}

1. Ardika, R. G., \& Bhima, S. K. L. (2016). Hubungan Antara Pengetahuan Perawat Tentang Rekam Medis Dengan Kelengkapan Pengisian Catatan Keperawatan: Di bangsal penyakit dalam RSUP Dr. Kariadi Semarang periode 1-31 Januari 2016. Semarang: Fakultas Kedokteran.

2. Budiman, R. (2013). Kuesioner Pengetahuan dan Sikap dalam Penelitian Kesehatan. Jakarta (ID): Salemba Medika.

3. Faizin. (2013). Hubungan Tingkat Pendidikan Dan Pengetahuan Tentang Mengisi Rekam Medis Di Rsu Pandan Arang Kabupaten Boyolali. Surakarta: Universitas Muhammadiyah Surakarta.

4. Indar. (2013). Faktor Yang Berhubungan Dengan Kelengkapan Rekam Medis Di RSUD $H$. Padjonga Dg. Ngalle Takalar. Takalar: Jurnal Administrasi dan Kebijakan Kesehatan Indonesia.

5. MOHAMAD KASIM, M. A. 2016. Peningkatan Kualitas Pelayanan dan Pendokumentasian Asuhan Keperawatan dengan Metode Tim. NurseLine Journal, 1.

6. PAMUNGKAS, A., HARYANTO, T., WORO, E. 2015. Identifikasi ketidak lengkapan dokumen rekam medis rawat inap di RSUD Ngudi Waluyo Wlingi. Jurnal Kedokteran Brawijaya, 28, 124-128.

7. PIRKLE, C., M., DUMONT, ALEXANDRE., ZUNZUNGUI, MV. 2012. Medical recordkeeping, essential but overlooked aspect of quality of care in resource-limited setting. International journal for Quality in Health care 24, 6, 564567.

8. PYRENE, M. B. 2015. Management of medical records for health care services delivery at the victoria public hospital in the Eastern Cape Province: South africa. Master, University of Forth Hare.

9. Pribadi. (2012). Analisis Pengaruh Faktor Pengetahuan, Motivasi, Dan Persepsi Perawat Tentang Supervisi Kepala Ruang Terhadap Pelaksanaan Dokumentasi Asuhan Keperawatan Di Ruang Rawat Inap Rsud Kelet Provinsi Jawa Tengah. Jepara: Program Pascasarjana Universitas Diponegoro.

10. Riyantika. (2018). Hubungan Antara Pengetahuan Dokter Tentang Rekam Medis dengan Kelengkapan Pengisian Data Rekam Medis Dokter yang Bertugas di Bangsal Anak RSUP Dr. Kariadi Semarang Periode 131 Agustus 2018. Semarang: Faculty of Medicine.

11. Sally. (2013). Hubungan Tingkat Pengetahuan Perawat Tentang Rekam Medis Dengan Kelengkapan Pengisian Catatan Keperawatan Di Rumah Sakit Nur Rohmah Wonosari. Yogyakarta: Politeknik Kesehatan Permata Indonesia.

12. SARAVI MB., A. Z., SIAMIAN H., FARAHABADI BA., GORJI 
$\begin{array}{lrr}\text { HA., MOTAMED } & \text { N., } \\ \text { FALLAHKHARYEKI } & \text { M., } \\ \text { MOHAMMADI R. } & 2016 .\end{array}$

Documentation of Medical Record in Hospitals of Mazandaran University of Medical Sciences in 2014: a Quantitative Study. Acta Informatica Medica, 24, 202-206.

13. SUDRAJAD, I., SUGIARTI, IDA 2015. Hubungan Kecepatan Penyediaan Dokumen Rekam Medis Rawat Jalan dengan Tingkat Kepuasan Pasien. Jurnal Manajemen Informasi Kesehatan Indonesia, 3 No 1.

14. ULFA, M., M., SUNDARI, SRI., ISTIOWATI, E. 2017. Evaluation of medical record completeness based on KARS (Komisi Akreditasi Rumah Sakit) Standar 2012 at Muhammadiyah Hospital of Ponorogo Indonesia. International Journal of Scientific and Research Publication, 7.

15. YUDHOYONO, S. B., AKBAR, P. 2009. Undang-Undang RI N0 44 Tahun 2009 Tentang Rumah Sakit. In: SAKIT, R. (ed.). 